bulb and cereural peduncle with similar lesions of the cerebellum and con: equently masking of true cerebellar sympt ims bv bulbar ones. He gives illustrative cases, but not in children.

The symptoms that have been ascribed to disease of the cerebellum are various, but among those of most constant occurrence mu- $t$ be mentioned headache, vomiting. "compelled" movements, and a kind of ataxia called cerebellar titubation. ${ }^{3}$ In some instances, especially in tumours, these symptoms have been very marked and characteristic, but, on the other hand, cases have occurred where a definite cerebellar lesion existed wichout any symptoms leading to a suspicion of its existence. In our case the existence of headache was doubtful and vomiting was practically absent. This latter symptom, which may occur in bæmorrhage into any part of the brain, was not considered pathognomonic of cerebellar lesions by Nothnagel, who noted that it was frequently wanting under such circumstances. In so young a child it was not possib'e to determine if any incoördination was present, and with regard to this symptom it may be mentioned that it is doubtful whether disturbance of coördination without paralysis has ever been seen in cases of simple lesions of long standing which do not exert mechanical pressure on surrounding parts. Similarly, "compelled" movements and paralysis are to be referred to injury of the crura cerebelli rather than to the affection of the cerebellum itself. ${ }^{*}$ The fart of hæmorrhagic cysts of considerable size having been fourd in this region in cases where no symptoms have remained after the immediate effects of the iujury have passed off proves that motor paralysis is not a necesearv symptom of rerebellar disease. ${ }^{5}$ Levers and Ollivier (Archiv s Générales, 1862) state that the eye alone of all the organs of sense is affected in disease of the cerebellum, and that strabismus, pupillary changes, and gradaully increasing amblyopia and amaurosis result. These observers consider that headache, irregular movements of the limbs and ocnlar muscles, with amaurosis constitute the only intrinsic symptoms attributable to cerebellar disease. Bilateral mydriasis has been observed several times in abscess of the cerebellum. ${ }^{6}$ The amaurosis has generally been explained by implication of the neighbouring corpora quadrigemina, but, as will be seen from the illustration, they were not directly affected in our case, though possibly there may have been pressure from surrounding exudation. But Longet attributes it to the connexion of the fifth pair with the middle cerebellar peduncle, and both Vulpian ${ }^{7}$ and Brown-Séquard ${ }^{8}$ refuse to admit pressure on the corpora quadrigemina as a cause of the blindness and consider it due to secondary changes in the brain or optic nerves or to sympathetic derangement analogous to that of vomiting in cerebral tumours. Unilateral blindness appears to be very rare. In our case the high temperature, which was so marked, and the respiratory spasms were obviously due to the implication of thermal and respiratory centres in the pons and medulla. The only cranial symptoms were amaurosis and possibly headache, as indicated by the screaming fits. These two were insufficient alone to justify a focal diagnosis, and while the high temperature and laryngeal spasm might have suggested a bulbar lesion there was nothing to indicate its possible nature.

The question now arises, Where was the embolus formed since no inflammatory cardiac lesion was found to account for it? Nothnagel ${ }^{9}$ says that in rare instances particles crumble off from a blood-clot which has become developed within the heart or pulmonary veins independently of any local inflammatory process and are carried away as emboli, the thrombosis being due to diminished efficiency of the heart's action produced by general diseases with marked cachectic diathesis. Emboli originating in this way have been found in connexion with carcinoma, tuberculosis, and empyema, and it is possible that the same may have happened in this case as a result of influenza occurring in a weakly infant. The same writer states that "autochthonous" thrombi have occasionally been observed in the case of cachectic persons where there was not the least appearance of alteration of the walls of the vessels or any condition which might give rise to

3 Vide Herard, Union Médicale, 1890.

4 Novat: Comptes Rendus, 1861.

5 Nothnagel : Ziemssen's Encyclopid̄ie, xii., 187.

7 Bulletins de la Société Anatomique, 1855, p. 22. 8 Journal de Physiologie, 1861.

9 Nothnagel : Ziemssen's Eincyclopädie. embolism. This explanation might hold good in the present case were not the appearances so characteristic of an embolus with its secondary tbrombus.

In seeking an explanation in the possibility of the migration of a blood-clot from the placenta or cord vîx a paten foramen ovale we bave carefully starebed for analingous cases in the post.mortem records of St. G orge's Hospital, the Victoria Hospital for Children, and the East London Hospitai for Children, and Dr. Colman has kindly informed us that there are no records of any cases of cereibrat softening in young children at the Hospital for Sick Children, Great Ormond-street. We find only two cases in any way similar from the Victoria Hospital, which we are kindly permitted to make use of by Dr. Walter Carr. The frst was aged two years, with chronic ill-health from bronebiectasis. In the last illness there was no hemiplegia on any eerebral sym ptoms. The necropsy showed blocking of the right posterior cerebral artery and softening round the leste zal ventricle. The beart was healthy. This was probable thrombosis of the artery in a case of chronic bronchiectasis. The second was aged seven weeks. It was a case of marasmus. The necropsy showed softening round the lateral ventricles, bot no blocking of the vessels. There were some small granu. lations on the mitral valve. This was probably embolism. It does not appear that either of these cases is precisely similar to that which we have recorded.

With regard to a patent foramen ovale Taylor states that though in general he found it closed after the establishment of respiration it was repeatedly open in children who bad survived birth several hours. Billard gave the second and third days as the date of closure and Orfila ${ }^{\mathrm{I} 0}$ stated that the peculiar parts of foetal circulation were rarely obliterated before the eighth or tenth day after birth, the foramen ovale closing last. According to Els süssern ${ }^{11}$ these vessels remair open some time after birth, but it is not possible to determine accurately by days the period of their closure, complete closure taking piace within the first six weeksafter birth. And we find on searehing the post-mortem records at St. George's Hospital that the foramen ovale in. some cases remains patent much longer than is generally supposed, it not being an infrequent oecurrence to find it open as late as two months in children who showed no symptoms of congenital heart disease during life. So far as we know, this theory has never been advanced as an explanatiori of cerebral softening in young infants; but since it is probable that after the separation of the urabilical cord a clot forms in that part of the umbilical vein which will eventually become the round ligament of the liver, it is at any rate possible that such a clot may become dislodged and pass vith a patent foramen ovale direct to the brain. Without laying undue stress on this idea we offer it as a suggestion that may explain some obscure cases in early infancy.

\section{ANTI-DIPHTHERITIC SERUM AND ITS PREPARATION. ${ }^{1}$}

BY T. J. BOKENHAM, M.R.C.S. ENG., L.R.C.P. LOND LATE RESEARCY SCHOLAR, BRITISH MIEDICAE ASSOCYATTON.

THE subject of Sero-Therapeutics has already been dealt with in such detail in the medical journals that some excuse is perhaps needed to justify one in bringing it before the Section of Pathology at this meeting of the British Medical Association. The journals have of course been full of the results obtained by sero-therapeutics in the treatment of diphtheria, and they have also from time to time contained accounts more or less detailed of the mode of preparation, testing, and issuing the serum for use from the various laboratories in England and abroad. During the past two years, however, I have given a great part of my time to the preparation of anti-diphtheritic serum and to studying the most suitable means for securing its uniform activity. During that time I have received very numerous letters from practitioners asking for all sorts of details as to the method of preparation; how uniform poteney is secured, how the tests are carried out in my own laboratories, and how the

10 Médecine Légale, 1848, ii., 210.

11 Medical Times and Gazette, 1853, p. 530.

1 Read in the Section of Pathology at the annual meeting of the British Medical Association held at Caritisle, 1896 . 
serum should be used in actual practice. These showed me that something was needed in addition to the descriptions which had appeared from time to time; and I thougtct the present meeting afforded a very excellent opportunity for giving as briefly as possible a practical demonstration of the whole of the processes employed in preparing antidiphtheritic serum, commencing from the selection of the diphtheria bacillus destined to produce the toxin needed for immunisation, and finishing with a description of the technique of the method by which the serum is put into Gottles for use.

The Diphtheria Bacillus to be selected.

Roux and Bebring found that the best method of preparing . 3 strong toxin was to cultivate the bacillus in a free current of oxygen, and Roux finally employed, and employs still, rery wide, flat liasks through which a current of air can be continuously drawn by means of a suction pump. These tlasks are capable of holding a large quantity of bouillon in a layer of small depth. Roux inoculates these flasks and allows the bacilli to grow at a temperature of $37^{\circ} \mathrm{C}$. for three weeks or a month, possibly longer, with a constant surrent of air passing over the surface. The method of Roux thas been very widely adopted and is still employed in most laboratories. In the course of last year, however, I paid a risit to the Institut Sero-Therapique at Brussels and studied the methods employed by my friend, Dr. Funck, the director of that inctitute. His results convinced me that it was by no means necessary to employ the complicated method of aeration devised by Rour, and that by using a very virulent hacillus a toxin culd be obtained quite strong enough for wrdinary purposes-indeed, many times stronger than the Behring "normal toxin." Since that time I have therefore abandoned the method of Roux and adopted one similar to that which I saw in action at, Brussels.

It is a matter of great importance to observe the mode of growth of the bacillus itself. In order to obtain an active toxin it is desirable that the bacillary growth should take place chief $y$ in the form of a dense white pellicle on the surface of the bouillon. The bacilli as they multiply are then brought into contact with a free supply of oxygen and form their toxic products under the best possible conditions. It is also most important to keep the flask undisturbed from the moment that the pellicle has commenced to form, in order to avoid breaking up the film of bacilli. After about a fortnight or three weeks of incubation at $37^{\circ} \mathrm{C}$. the culture may be filtered through a sterile porcelain filter, and if the wrocess has been carried out with proper care and a sufficiently virulent bacillus employed it will be found that the toxin yielded is of such a strength that a dose of from 1 to is centigrammes is fatal (within forty-eight hours) to small guinea-pigs. It is the experience both of Dr. Funck and myself that mnless a good tirm pellicle is formed the resulting toxin is seldom satisfactory in power.

Before using swch toxia for immunising horses one should first determine its activity. This is ascertained by tests rarried out on small guinea-pigs. I have not been satissied with any toxin for immunising purposes unless the cetbal dose is at the most five centigrammes, such a dose producing death in a 300 gramme guinea-pig within about iorty-eight hours. Such a toxin I have employed constantly "or nearly twelre months, and it will be observed that it is a good deal more powerful than the toxin adopted by Behring as a standard. In using this powerful poison the selection of the sreed of horses to be subjected to the immunising process is of great importance. 'I'hat was brought to my notice by a perusal of the admirable results obtained in Ctaly last year. Some samples of antitoxin which I obtained from Italy were far more active than any obtainable relsewhere. I sought for some explanation of it and, I believe, was successful in finding one. In Italy the animals used in preparing serum were, I understand, thorougbbred horses obtained from racing stables. Such animals seemed to stand the injection of toxin extremely well; they showed very slight reaction, eitber local or general ; the process of immunisation was extremely rapid; and the condition of immunity when once established could be maintained with a minimum of trouble. The rirk of losing animals as the result of an over-dose of poison seemed also to have been reduced to a minimum. Since making that discovery I have rilways endeavoured to select horses which are as well bred as possible. and have grarially succeeded in weeding out ilom the stables several of the old horses which were first used and replacing them by thoroughbreds. It is quite a mistake to suppose, as has been frequently stated by writers in the medical journals, that any old horse is good enough for the production of antitoxin. With old horses the process of immunisation is unnecessarily long and the risk of losing them during that process is enormous.

$$
\text { The Process of Immunisation. }
$$

For the first few injections it is necessary to use extremely small and carefully-measured doses of toxin. $R$ ux recommended that the toxin used for the tirst few injections should be mixed with some mirigating substance, such as iodine trichloride or Gram's fluid. Such a mixture may be nenessary in low-bred animals, but it is not so necessary in the case of thoroughbreds. I have found that a thoroughbred horse can almost invariably resist without undue disturbance a dose of 025 c.c. of a toxin which is fatal to guinea-pigs in the dose of 4 or 5 centigrammes.

The process of immunisation, as is well known, consists in the coatinuous adwinistration of graduated doses of toxin until the animal treated shows neither serious local nor general disturbance as the result of the injections. The initial injections, being small in bulk, may be conveniently made under the skin of the shoulder, but when larger doses are required it is found more convenient to give the toxin by intravenous injection, and I bave a syringe which I find very convenient for the purpose. It consists of the ordinary serum syringe to which I have added a three-way stop-cock. To the main nozzle is attached an injection needle by means of a rubber connexion; to the side branch is attached another rubber tube, which is passed throngh a cotton-wool plug into a bottle containing toxin. By this arrangement any amount of toxin may be injected with a minimum of trouble and inconvenience both to the overator and the animal. I have found it extremely useful in practice.

At various stages of the immuni-ation it is desirable to test the antitoxic power possesned by the serum. For this purpose a little blo'd can be obtained from the jugular vein by means of a small aspirating syringe. The protective power of the serum obtained from this blond can be readily ascertained by test experiments on guinea-pigs. After three or four months if the immunisation prucess bas been carried on carefully and steadily the serum should possess an antitoxic power of at least from 500 to 700 units per 10 cubic centimetres. By the employment of such powerful toxins as those which I have already describer it is no longer necessary to wair from six to twelve months before being able to obtain a serum of suftivient strength tor clinical use.

\section{Method of Bleeding the Animals.}

There are $t w$, methods by which the blood can be obtained in sufficient quantities for practical $u$ se. The fir it is that generally employed, and consists in the insertion of a large cannula into the jugular vein which has been previously distended with blood by means of a cord passed round the base of the neck and pulled tight. To the end of the cannula is attached an indiarubber tube which is placed in communication with the bottle destined to receive the blood. In this manner the blood can be obtained in an aseptic condition provided the instruments and collecting flasks be sterilised previou-ly to use. In some cases, however, whon the animal has only a small, or not readily accessible, jugular vein, it is somewhat diffisult to insert the canvula and the process occasionally also becomes tedious from coagulation of the blood taking place somewhere in the lumen of the tube. Another and somewhat more convenient method is one which I have myself adopted. No special care is necessary to secure complete asepsis, and the only instrument required is an ordinary sharp fleam such as is employed by veterinary surgeons. With this instrument I make an incision in the course of the jugular vein and collect the stream of blood, which issues with some force from the wound, in flasks capable of holding about one and a half litres. These tlasks are of a form commonly known as filter-flasks. When filled they are transferred to an ice safe or cool chamber, where they are allowed to remain sheltered from light from twentyfour to thirty-six hours in order to allow complete coagulation to take place. A bout eight litres of horses' blood will, as a rule, yield at least three and a half litres of clear serum.

The next point is to ascertain the antitoxic value of the serum. For this purpose one must take a series of guineapigs of fairly uniform weight. Une of these is used as a control animal, and receives a dose of diphtheria poison corresponding to the lethal amount. The others receive mixtures of various proportions of the sfrum which is to be tested with ten times the lethal dose of diphtheria toxin. 
The following tables will give the details of the test above alluded to.

Results of Investigations.

\begin{tabular}{|c|c|c|c|c|c|c|}
\hline 离 & 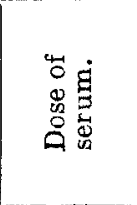 & 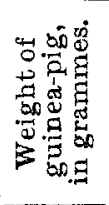 & 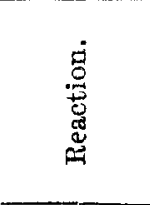 & 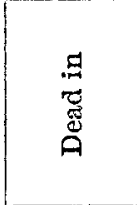 & 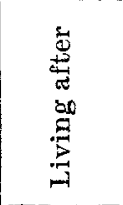 & 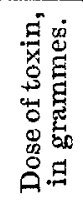 \\
\hline $\begin{array}{l}\operatorname{Jan} .30 \mathrm{th}, \\
1895 .\end{array}$ & 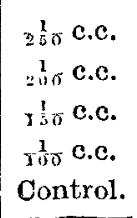 & $\begin{array}{l}490 \\
475 \\
470 \\
500 \\
495\end{array}$ & $\begin{array}{c}\text { Swelling. } \\
\text { " } \\
\text { (?) " } \\
\text { Nil. } \\
-\end{array}$ & $\begin{array}{l}52 \text { hours. } \\
56 \quad " \\
- \\
- \\
40-48 \mathrm{hrs} .\end{array}$ & $\begin{array}{c}- \\
- \\
6 \text { days. } \\
6= \\
-\end{array}$ & $\begin{array}{c}0.2 \\
" \\
" \\
" \\
"\end{array}$ \\
\hline $\begin{array}{l}\text { eb. 11th, } \\
1895 \text {. }\end{array}$ & $\begin{array}{l}=\frac{1}{60} \text { c.c. } \\
=\frac{1}{20} \text { c.c. } \\
\frac{1}{100} \text { c.c. } \\
\frac{10}{76} \text { c.c. } \\
\text { Control. } \\
\end{array}$ & $\begin{array}{l}400 \\
385 \\
390 \\
424 \\
408\end{array}$ & $\begin{array}{c}\text { Swelling. } \\
\text { " } \\
\text { Nil. } \\
- \\
\end{array}$ & $\begin{array}{c}54 \text { hours. } \\
55 \quad " \\
- \\
50 \text { bours }\end{array}$ & $\begin{array}{c}- \\
- \\
7 \text { days. } \\
7 \text { " } \\
-\end{array}$ & $\begin{array}{l}0.2 \\
" \\
" \\
" \\
",\end{array}$ \\
\hline $\begin{array}{l}\text { Mar. 6th, } \\
1895\end{array}$ & 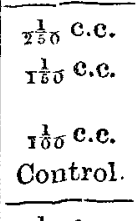 & $\begin{array}{l}305 \\
295 \\
\\
310 \\
328\end{array}$ & $\begin{array}{l}\text { Swelling. } \\
\text { slight } \\
\text { swelling. } \\
\text { Nil. } \\
-\end{array}$ & $\begin{array}{c}3 \text { days. } \\
- \\
40-48 \mathrm{hrs}\end{array}$ & $\begin{array}{c}- \\
6 \text { days. } \\
6 " \\
-\end{array}$ & $\begin{array}{c}02 \\
"\end{array}$ \\
\hline $\begin{array}{c}\text { Iay } 9 \text { th, } \\
1895 .\end{array}$ & 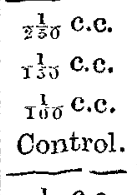 & $\begin{array}{l}305 \\
290 \\
325 \\
300\end{array}$ & $\begin{array}{l}\text { Swelling. } \\
\text { (?) , } \\
\text { Nil. } \\
-\end{array}$ & $\begin{array}{c}4 \text { days. } \\
- \\
- \\
48 \text { hours }\end{array}$ & $\begin{array}{l}- \\
6 \text { days. } \\
6 " \\
-\end{array}$ & $\begin{array}{l}" \\
",\end{array}$ \\
\hline $\begin{array}{c}\text { June15th, } \\
1895 .\end{array}$ & 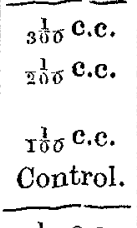 & $\begin{array}{l}280 \\
300 \\
\\
293 \\
305\end{array}$ & $\begin{array}{c}\text { Swelling. } \\
\text { slight } \\
\text { swelling. } \\
\text { Ni1. } \\
-\end{array}$ & $\begin{array}{c}74 \text { hours. } \\
- \\
- \\
52 \text { hours. }\end{array}$ & $\begin{array}{l}- \\
6 \text { days. } \\
6 \quad "\end{array}$ & $\begin{array}{c}0.25 \\
="\end{array}$ \\
\hline $\begin{array}{l}\text { July 12th, } \\
1895 .\end{array}$ & $\begin{array}{l}\frac{1}{20} \text { c.c. } \\
\frac{\pi}{15 \sigma} \text { c.c. } \\
\frac{1}{100} \text { c.c. } \\
\text { Control. }\end{array}$ & $\begin{array}{l}285 \\
270 \\
290 \\
257\end{array}$ & $\begin{array}{c}\text { Swelling. } \\
\text { Nil. } \\
y \\
\end{array}$ & $\begin{array}{l}7 \text { days. } \\
- \\
52 \text { hours. }\end{array}$ & $\begin{array}{c}7 \text { days. } \\
7 \text { ", } \\
-\end{array}$ & $\begin{array}{l}0 \cdot 1 \\
", \\
", \\
, "\end{array}$ \\
\hline $\begin{array}{l}\text { Sept. } 9 \text { th, } \\
1895 .\end{array}$ & $\begin{array}{l}\frac{1}{20 \pi} \text { c.c. } \\
\frac{1}{1 \frac{1}{5} \sigma} \text { c.c. } \\
\frac{1}{125} \text { c.c. } \\
\text { Control. }\end{array}$ & $\begin{array}{l}233 \\
250 \\
251 \\
262\end{array}$ & $\begin{array}{c}\text { Slight } \\
\text { swelling. } \\
\text { Nil. } \\
\text {, } \\
-\end{array}$ & 2 days. & $\begin{array}{l}6 \text { days. } \\
6 " \\
6 " \\
=\end{array}$ & $\begin{array}{c}" \prime \\
0.65\end{array}$ \\
\hline $\begin{array}{l}\text { Dec. } 5 \text { th, } \\
1895 .\end{array}$ & 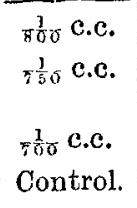 & $\begin{array}{l}303 \\
290 \\
317 \\
310\end{array}$ & $\begin{array}{l}\text { Swelling. } \\
\text { Slight } \\
\text { swelling. } \\
\text { Nil. } \\
-\end{array}$ & $\begin{array}{c}7 \text { days. } \\
- \\
- \\
2 \text { days. }\end{array}$ & $\begin{array}{c}7 \text { days. } \\
7 \text { " } \\
-\end{array}$ & $\begin{array}{c}1 \cdot 0 \\
"\end{array}$ \\
\hline $\begin{array}{c}\text { May 5th, } \\
1896 .\end{array}$ & 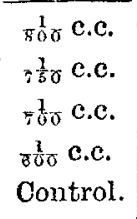 & $\begin{array}{l}325 \\
310 \\
290 \\
299 \\
360\end{array}$ & $\begin{array}{c}\text { Swelling. } \\
\text { ", } \\
\text { (?) ," } \\
\text { Nil. } \\
-\end{array}$ & $\begin{array}{c}4 \text { ảays. } \\
- \\
- \\
- \\
53 \text { hours. }\end{array}$ & \begin{tabular}{l}
\multicolumn{2}{c}{-} \\
6 days. \\
$6 \quad "$ \\
$6 \quad "$ \\
-
\end{tabular} & $\begin{array}{c}0.2 \\
" \\
" \\
" \\
002\end{array}$ \\
\hline
\end{tabular}

It will be observed that the above tables, which are taken from my note-book, extend over a period of about eighteen months, and I would mention that they are typical of many dozens of similar investigations all of which time does not allow me to bring forward. In examining the details of these tables it will be observed that the doses administered are not uniform throughout. During the earlier periods a different standard of immunity-value was adopted, and a serum was issued possessing such a strength that one gramme would surely protect 50,000 grammes of guinea-pig against a lethal dose of diphtheria toxin. In the latter records, which correspond roughly to the period during which the Behring standard was adopted, the serum was tested in regard to its power of protecting small guinea-pigs against ten times the lethal dose of toxin-thus, a bottle which contained 10 cubic centimetres and was said to have an immunity-value of 600 units contained a serum of which $\frac{1}{60}$ th of a gramme completely protected the animal against ten times the lethal dose of toxin.

The serum having been tested and found active has to be sterilised before it can be used with safety. For that purpose I have had a large pressure filter constructed, somewhat after the model originally designed by d'Arsonval through which the serum can be forced by means of pressure supplied by liquefied carbonic acid gas, the pressure required being regulated by means of one of the very convenient pressure valves made for me by Messrs. Uhlmann ans Keutgen of Lime-street, London, E.C.

\section{FIG. 1.}

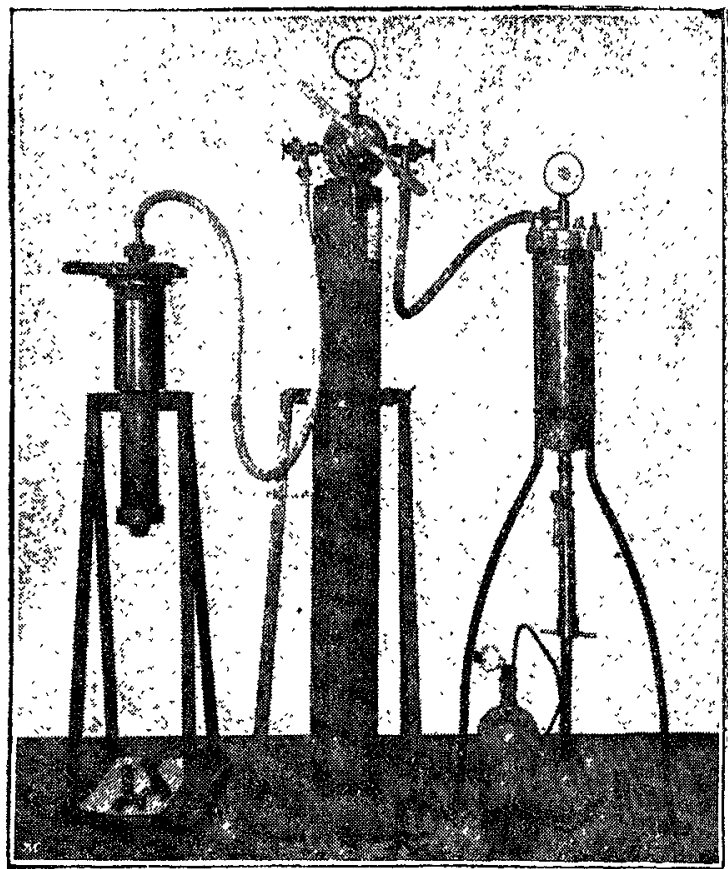

Apparatus used for filtering serum, showing two forms of:pressure tilter, cylinder of $\mathrm{CO}_{2}$, regulating valve, and receiver for tiltered serum.

[Mr. Bokenham then gave a demonstration of the process by means of the apparatus as shown in Fig. 1 and continued :]

It will be seen that the conditions under which the filtration takes place are such as to almost absolutely preclude the possibility of the serum which has been sterilised by

EIG. 2.

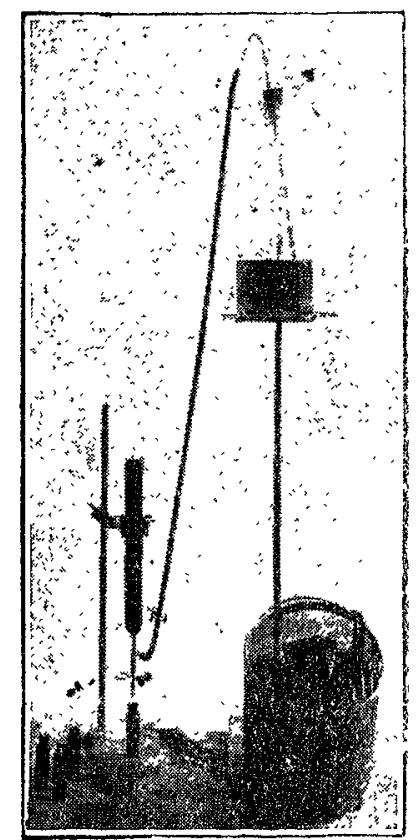

Apparatus used in decanting and measuring sernwa.

passage through porcelain filter tubes from becoming agaio contaminated by the introduction of chance microbes from the air. In order to carry out the rest of the process and to charge each bottle with the required quantity of serum I employ burettes of the model which is here shown (Fig. 2). By their use the measurements can be carried out with the greatest possible facility and with practically no risk of contamination.

I may mention, finally, that no single bottle of serum is allowed to leave my laboratory for clinical use until it has been securely corked and sealed under my direct supervision. Devonshire-street, w. 